\title{
Freies Ermessen of Fisheries Criminal Investigators in Indonesia's Exclusive Economic Zone (ZEEI)
}

\author{
Agung Pramono ${ }^{1} \quad$ I Nyoman Nurjaya $^{2} \quad$ Bambang Sugiri $^{3} \quad$ Dhiana Puspitawati $^{3}$ \\ 1. Ph.D Candidate at Faculty of Law, Brawijaya University, Indonesia \\ 2. Professor of Legal Anthropology at Faculty of Law, Brawijaya University, Indonesia \\ 3. Lecturer at Faculty of Law, Brawijaya University, Indonesia
}

\begin{abstract}
In law, especially in the field of fisheries, there is a tug of war and overlapping of Freies Ermessen between police investigators and other investigators such as the Indonesian Navy (TNI AL), as well as the Police and Civil Servants (PPNS) themselves as regulated by law certain laws/specifics. Deviations occur because of a shift in orientation from the criminal justice system that prioritizes coordination and integration into subsystems that are centered on each foreign institution that can lead to inter-sectoral interests. The implementation of the Freies Ermessen specifically for PPNS has not been the same or different from the rules stipulated in the criminal procedure code, as a general rule, giving rise to diverse interpretations of civil servant investigators through discretion in the form of inconsistencies and conflicting policy norms. The purpose of this study was to determine Freies Ermessen investigating fishery's criminal offenses in Indonesia's exclusive economic zone. This research is legal research with the law approach and conceptual approach. The analysis technique in this research was done analytically prescriptive. The results showed that everything related to the application of law in Indonesia's exclusive economic zone must be guided by international sea treaties that are applied to Indonesian laws and regulations, namely the Indonesian exclusive economic zone law because that's Law is a derivative of the United Nations Conference on the Law of the Sea 1982 (UNCLOS 82).
\end{abstract}

Keywords: Freies Ermessen, Investigators, Indonesia's Exclusive Economic Zone (ZEEI).

DOI: $10.7176 / \mathrm{JLPG} / 90-04$

Publication date:October $31^{\text {st }} 2019$

\section{A. Introduction}

The Unitary State of the Republic of Indonesia is the largest archipelago in the world, the number of large and small islands of nearly 17500 spread from Sabang to Merauke. Nearly $70 \%$ of its territory is an ocean with a wealth of minerals and fisheries. This is a gift from God who is thankful and used as capital for the Indonesian people for the prosperity of their people. One of the natural wealth of the sea is that fisheries are still not managed optimally. Because the entrepreneurs involved in managing fish wealth only profit, they sometimes also use methods that are not fair. This is an irresponsible act that also results in damaging the marine environment and the surrounding environment. Utilization of marine wealth must be followed by good and directed management, so that marine wealth does not suffer damage that harms us all. If the wealth of fisheries can be managed well, of course, the utilization will get results that will satisfy. Thus it appears that the ocean is a field that can still accommodate a variety of jobs related to fisheries. In general, fishery products other than for basic daily needs are very sufficient and the rest are sold to other people. Likewise at the national level, excess will be exported to other countries. Sea fishing has the potential to become a field that has a bright future both in terms of technical and equipment that is still open for development. In the future, it will also require workers who master modern fisheries management and technology. If fisheries can be managed well and professionally the results will increase, so that it can increase the country's income which in turn can create prosperity.

To be able to carry out fisheries management as expected, an adequate rule of law is needed. This is in line with our country as a state of law. The law was deliberately created to regulate people's behavior. Besides that, the law is also used as an "agent of change" that can change people's actions and is used as a social control that forces the citizens to heed and obey the rules of the applicable law ${ }^{1}$. Since 1985 (Law No.9 of 1985 concerning fisheries) the government has formed several regulations or laws in the field of fisheries than in 2004 (Law Number 31 of 2004) was changed and in 2009 (Law number 45 of 2009) there were changes again along with technological developments and environmental changes. These changes are in order to be substantially acceptable to the community and arises legal awareness so as to overcome the fisheries problems in our homeland. The Ministry of Maritime Affairs and Fisheries is an agency given Freies Ermessen by the government to carry out national fisheries management. To expedite the settlement of cases and litigation, the government also established a special court for fisheries to resolve fisheries violations, especially in the criminal field. Fisheries courts were established in North Jakarta, Pontianak, Medan, Bitung and Tanjung Pinang and Ranai.

\footnotetext{
${ }^{1}$ Gatot Supramono, S.., MHum, Hukum Acara Pidana Dan Hukum Pidana Di Bidang Perikanan,Rineka Cipta, Jakarta, 2011, p. 4.
} 
Nationally, the formation of laws and government regulations on fisheries is to organize management of marine affairs in the field of fisheries, because with the vast extent of the sea area and the limited facilities, the sea control in implementing law is very difficult in supervision and detection carried out by law enforcement agencies. This situation makes the sea potential and easy for violations of the law to occur. Likewise, based on the principles of the sea as proposed by Hugo Grotius in his book mare liberium published in 1609 which in essence that freedom to sail at sea and also alludes to freedom to catch fish ${ }^{1}$. Then the international community also formally regulates state authority over the sea. The International Community through an international convention has made international sea law such as Unclo's 1982. Indonesia has ratified it into Law number 17 of 1985 concerning the Ratification of Unclo's. In Unclo's the sea is divided according to zones, one of which is the Exclusive Economic Zone, namely Article 55 of the convention emphasizing that the exclusive economic zone as an area of water (sea) located outside and adjacent to the territorial sea, subject to special legal regimes which This chapter is determined according to which the rights and jurisdiction of the coastal state, the rights, and freedoms of other countries are governed by the relevant provisions of this convention. This special legal regime appears in the specificity of the law that applies to the exclusive economic zone as an integration which includes;

a. Sovereign rights, jurisdiction and obligations of coastal states;

b. The rights and freedoms of other countries;

c. Freed sea freedoms; and

d. The rules of international law as specified in the convention

Indonesia's obligation as a coastal country must announce the EEZ Act which regulates it, namely Law number 5 of 1983 concerning EEZ. Thus the absolute sea must be arranged and regulated properly with the correct national and international legal instruments and agreed upon and complied with by the international community. This is so that marine resources can be used for the prosperity of the people of a country that has a sea and a country that does not have a sea. However, EEZ still leaves problems because the international community is not yet the same in understanding this regime. In accordance with Unclo's in EEZ, coastal countries have sovereign rights instead of absolute sovereignty as in the territorial sea. This makes it different in making laws and regulations enforced in EEZ, one of which is that other countries that do not have EEZ must also be regulated to be able to explore and exploit especially fisheries. Likewise, in order to manage this EEZ more orderly, law enforcement becomes more important so that the application of the law still leads to justice. The government in regulating law enforcement in EEZ has given Freies Ermessen to the Navy, Employees of the Ministry of Maritime Affairs and Fisheries but there are still differences especially the underlying reasons for granting the Freies Ermessen.

\section{B. Methodology}

This type of research is normative juridical research which is a process to find the rule of law, legal principles and legal doctrines in order to answer the legal issues encountered. ${ }^{2}$ The research approach used legislation approach and conceptual approach. The source of legal material used is primary legal material (legal material that has a determined legal authority and has binding power, consisting of statutory regulations), secondary (legal material that provides an explanation of primary legal material, such as academic texts, the results of legal research and others) and tertiary (legal material that can provide guidance or explanation to strengthen primary and secondary legal materials, such as those derived from encyclopedias and legal dictionaries). The analytical technique in this research is prescriptive analytic, which aims to produce a prescription of what should be the essence of legal research that adheres to the character of law as an applied science. ${ }^{3}$

\section{Results and Discussion}

\section{The Origin of the " Freies Ermessen of Fisheries Investigators" in Indonesian Exclusive Economic Zone (ZEEI)}

Understanding of Freies Ermessen According to H.D.Stoud cited by Riduwan HB is:

"overall rules relating to the acquisition and use of government authority by public law subjects in public law relations ${ }^{4}$. According to HD Stoud the Freies Ermessen consists of 2 elements namely the existence of the rule of law and the nature of its legal relationship. Delegation of authority to institutions that implement it must first be determined by the laws and regulations, both in the form of laws, government regulations and lower level forms. The nature of legal relations is the nature that has to do with regard to law, legal relations exist that are public and private. According to Ateng Syafrudin there is a difference between freies Ermessen and authority. Freies Ermessen is what is called formal power, power that comes from the power given by the law. Authority

\footnotetext{
${ }^{1}$ Mochtar kusumaatmaja, hukum laut internasional. Binacipta, Bandung, 1978, p. 12.

${ }^{2}$ Peter Mahmud Marzuki, Penelitian Hukum (Jakarta : Kencana Prenada Media, 2001), p.35.

${ }^{3}$ Purnadi Pubacaraka and Soerjono Soekanto, Perihal Kaedah Hukum, (Bandung : Alumni, 1978), p.9.

${ }^{4}$ Ridwan Eko Prasetyo, Hukum Acara Pidana, (Bandung: Pustaka Setia, 2015), p. 110.
} 
(competence) is part of the Freies Ermessen whose scope is a public legal action ${ }^{1}$.

In the rule of law, legality is known as its main pillar and is one of the main principles that is used as the basis for every administration and state in every state of law, especially for the rule of law and the continental system. Philipus M. Hadjon stated that Freies Ermessen was obtained through three sources, namely attribution, delegation, mandate. The Freies Ermessen of attribution is usually outlined through the division of state power by the Basic Law, the Freies Ermessen of the delegation and the mandate is the Freies Ermessen that comes from delegation ${ }^{2}$.

a. Indonesian Navy National Army officers as investigators at Indonesian Exclusive Economic Zone, based on article 9 of Law number 34 of 2004 concerning the TNI, article 14 of Law number 5 of 1983 concerning ZEEI and based on article 73 (2) of Law number 45 regarding amendments to Law number 312004

Since the promulgation of articles 13 Territorial EEZ en Maritime Kringen Ordonantie 1939 the Indonesian Navy has been given several legal Freies Ermessen to maintain and oversee compliance with provisions in the marine aspects including legal aspects. The law is a Dutch product which is still a reference for the Navy in carrying out law enforcement. After the independence of several laws that gave the Indonesian Navy Freies Ermessen as law enforcement officers, namely law number 5 of 1983 concerning EEZ, law number 17 of 1985 concerning Ratification of UNCLO'S, law number 45 concerning amendments to Law number 31 of 2004, law number 34 of 2004 concerning the TNI. Freies Ermessen was given to the Navy as law enforcement include the process of investigation, investigation, and prosecution. Historically, the sea in an archipelago like Indonesia has a very strategic value and plays a very important role in national development. As an archipelago, the sea is certainly the foundation of national economic development, especially the exploitation and exploration of marine resources, therefore sea order is a requirement for the realization of the use of the sea as a source of the national economy. Sea order can be realized if marine management and management are carried out properly. Law enforcement at sea is the key to the realization of sea order, therefore law enforcement is needed that has the ability and means of supporting it which is very adequate. The Navy has facilities and infrastructure in the form of ships and bases scattered throughout Indonesia so that they can carry out law enforcement at sea until they reach the EEZ and free sea.

The history of law enforcement at sea has placed the Indonesian Navy as the first law enforcement officer at sea given Freies Ermessen by law. According to H.D. Stoud states that Freies Ermessen is "overall rules that are pleasing with the acquisition and use of governmental authority by subjects of public law in public law relations", while "attribution" is a method of giving authority by lawmakers themselves to a government organ, both existing and completely new. The Indonesian Navy has the authority because of the mandate of the Law (TZMKO, Unclo's and Fisheries Law) while the "Freies Ermessen" given is as law enforcement officers at sea/ZEEI, where previously there were no officials who received this authority. The Indonesian Navy received the attribution meaning Fremessen Ermessen from the norms of the positive law, not delegation or mandate. Especially in ZEEI, the Navy received Freies Ermessen and authority as law enforcement officers since the promulgation of Law number 5 of 1983 concerning ZEEI and Law number 17 of 1985 concerning ratification of Unclo's 82. Here the Indonesian Navy received purely directly from a statutory regulation as well as how so that this is truly a need for a positive legal instrument and if this is not met then law enforcement at sea cannot work.

b. Fisheries Civil Servant Investigators As Investigators In ZEEI, Based On Article 73 (2) Of Law

\section{Number 45 Concerning Amendments To Law Number 31 Of 2004 Concerning Fisheries}

Civil Servant Investigators or PPNS appear since the enactment of article 31 (2) of Law number 9 of 1985 concerning fisheries but it has not stated who the PPNS was given Freies Ermessen. Likewise, article 73 of Law number 31 of 2004 concerning fisheries in addition to mentioning PPNS is also the Navy and the national police, while article 5 of fisheries management areas include ZEEI. Article 73 (2) of Law 45/2009 states that in addition to the Indonesian Navy, fisheries PPNS has the authority to conduct investigations into criminal acts that occur in EEZ. This law does not explain Freies Ermessen the national police at ZEEI, so according to this law the national police do not have Freies Ermessen as investigators at ZEEI.

Freies Ermessen as a law enforcement officer in ZEEI was first given to the Indonesian Navy, but with this new fishery law, the Fremessen Ermessen was also given to PPNS fisheries. Here PPNS fisheries as investigators are the development of existing investigators namely the Navy, meaning that the granting of Freies Ermessen also does not consider other laws relating to Freies Ermessen investigators at ZEEI. In this case, one Freies Ermessen was given to 2 government agencies based on different laws with the same operational area, namely EEZ. Therefore, it means that Freies Ermessen as a law enforcement officer in ZEEI that has been regulated in one specific law then regulated again in another law with the same substance. In the legislation

\footnotetext{
${ }^{1}$ Ateng Syarifudin, Menuju Penyelenggaraan Pemerintahan Negara Yang Bersih Dan Bertanggung Jawab, Jurnal Pro Justisia Edisi IV, 4(1):12-26, 2000, p. 22

${ }^{2}$ Philipus M. Hadjon, Wewenang, paper, Universitas Airlangga, Surabaya, p. 112
} 
process if such a thing is found it is certainly necessary to synchronize without eliminating the meaning of the norms in the Act. The existence of 2 law enforcement officers having Ermessen's duties and Freies and the area of applying the same law will lead to legal problems and harm the examinee, here in the legislation process there are weaknesses which result in the resulting laws overlapping so that the purpose of forming these laws blurred.

\section{c. Indonesian National Police Based On Law Number 31 Of 2004 Concerning Fisheries}

Law number 5 of 1983 concerning ZEEI and Law number 45 of 2009 concerning amendments to law number 31 of 2004 concerning fisheries do not include the Republic of Indonesia police as law enforcement officers in ZEEI. In accordance with article 6 of Law number 8 of 1981 concerning the Criminal Procedure Code investigators are state police officers, while the enactment of the Criminal Procedure Code in the sovereign territory of the Republic of Indonesia is too territorial sea boundaries and does not include ZEEI. There are conflicting conditions between the National Police and fisheries PPNS in terms of Freies Ermessen in ZEEI, Indonesian republic police do not have Freies Ermessen as investigators in ZEEI but fisheries PPNS have Freies Ermessen as investigators in ZEEI. This happens because there is an overlap in the making of laws and regulations. The National Police as investigators since the founding of this Republic while the PPNS fisheries since the existence of the fisheries Act, so that the National Police has broader experience. The National Police as the supervisory coordinator of the investigators of civil servants and this oversight especially in the field of the investigation profession. With this position, giving Freies Ermessen to fisheries PPNS as investigators in ZEEI is not appropriate because the National Police as PPNS supervisors do not have these Ermessen Freies.

\section{Analysis results}

Theoretically, the formation of statutory regulations is essentially the formation of legal norms that apply outward and general in a broad sense. Legislation (Wettlijke Regeling) as a written decision of the state or government that contains instructions or patterns of behavior that are general in nature. A law contains good rules if it has the following characteristics ${ }^{1}$ :

a. General and comprehensive, which is the opposite of special and limited traits.

b. Universal, it was created to deal with future events whose concrete form was not yet clear. Therefore it cannot be formulated to deal with certain events.

c. He has the power to correct and improve himself. It is customary for a rule to include a Clause that includes the possibility of a review after mutual agreement.

Likewise, laws and regulations must have a high degree of predictability, namely being able to become a prospective law and be able to deal with all changes in the future. The legislation must contain certainty about the value at stake, meaning that there is a value that is protected by the regulation so that there is no need to debate about whether or not the value is accepted. Therefore, the formation of legislation that gives Freies Ermessen as law enforcement officers to the Navy and Fisheries PPNS is not in accordance with the theory and principles of making laws and regulations.

Related to the basis of statutory regulations, especially in the context of the formation of laws, according to Jimmy Asshiddiqie, a law must contain good legal norms which become the basis for the enforcement of these laws. One such basis is a juridical basis, wherein every formulation of the law must be placed in the consideration section " to remember" 2 . In the consideration "to remember" this must be drawn up in detail and precisely (1) the provisions of the 1945 constitution used as a reference including the mention of certain articles and paragraphs or sections of the 1945 Constitution must be determined precisely, (2) Other laws that are used as references informing the relevant law. In the preamble of Law number 45 of 2009 concerning amendments to Law number 31 of 2004 concerning Fisheries only includes the 1945 Constitution. Laws relating to Freies Ermessen law enforcement officers at ZEEI such as Law number 5 of 1983 concerning ZEEI, Law number 17 of 1945 concerning ratification of UNCLO'S 1982 and Law number 34 of 2004 concerning the TNI, are not included as consideration. This is a weakness of the fisheries law that has the potential to cause overlapping norms in the law. The importance of the juridical basis in the formation of these laws so that the laws that are formed have legal norms and are able to be effective because they can or will be accepted by the public nature and apply for a long time.

The big question that needs to be answered is why the government gave Freies Ermessen an investigation in EEZ to these two institutions? Meanwhile, the position of EEZ is not an absolute sovereign territory for Indonesia as regulated in the legislation. Operationally, it is also not regulated in law, the work relations of the two investigators have never been regulated because they adhere to their respective legal basis. Each of them works in accordance with the Criminal Procedure Code but their work areas are not regulated so both have the same work area in ZEEI, their goal is to capture and process perpetrators of fisheries criminal acts in ZEEI. In their operations they carry out independently from both planning and implementation, their independence is very strong because they carry out the mandate of the law but this can lead to problems that lead to legal aspects.

\footnotetext{
${ }^{1}$ Dr. Nomensen Sinamo, SH., M.H., Ilmu perundang-undangan, Jala permata aksara, Jakarta, 2016, p.11

${ }^{2}$ Dr. Nomensen Sinamo, SH., M.H., Ilmu perundang-undangan, Jala permata aksara, Jakarta, 2016, p.16.
} 
Since the beginning, the Navy was legally given Freies Ermessen as an investigator and set forth in the legislation namely TZMKO 1039 and article 14 of Law number 5 of 1983 concerning ZEEI as well as article 73 (2) of Law number 45 concerning amendments to Law number 31 of 2004 concerning fisheries. As a tool of the Indonesian Navy, indeed since its birth, it has been tasked with securing the oceans from various violations of the law, meaning that the Navy as the first state instrument was given security duties at sea before other officers. The facilities and infrastructure owned by the Indonesian Navy to conduct investigative activities in ZEEI are very adequate and with specific characteristics so that operations can be carried out routinely. The Indonesian Navy carried out Freies Ermessen in accordance with the applicable provisions, especially the law of the event starting from the investigation, investigation, and prosecution and executing when there was a permanent decision. On the other hand, investigators from the Ministry of Fisheries with limited facilities and infrastructure especially ships also conduct law enforcement operations at ZEEI. Thus in ZEEI, there are 2 law enforcers, both of whom work independently based on the laws that govern it. What became the legal basis for the PPNS KKP given Freies Ermessen as an investigator at ZEEI? The awarding of Freies Ermessen is based on the ability of the technical professional profession without considering ZEEI's position both in the territory of the Republic of Indonesia and international law on the sea. ZEE in accordance with international sea law has specificity because not only coastal countries have rights in ZEEI but also countries do not have beaches, so in determining the investigative apparatus in ZEEI must also consider the interests of other countries in accordance with Unclo's 82

The important questions that need to be answered are (1) why the Freies Ermessen were given to the two government law enforcement agencies as investigators at ZEEI, (2) what factors influenced the delivery of the Freies Ermessen, (3) what are the implications of giving Freies Ermessen as an investigative apparatus at ZEEI to the three officers. One of the weaknesses in the process of drafting the law is the synchronization process because our law system has not been neatly arranged, for example, a law in its consideration does not include a lot of the law that becomes a reference so that between the master law and the derivative law can be reversed. The most important thing is the ability to synchronize one law with another which has been considered very weak, so that there is the potential for overlapping, for example, legislation governing the investigative apparatus at ZEEI. Mismatch between laws is not only due to the weaknesses of the legislators but also because of outside influences for the benefit of certain groups, it means that the political aspects of the law are also strong. The overlapping law or the existence of duplication will certainly cause problems in its application because each apparatus is guided by the Law that gives Freies Ermessen, so this is very detrimental to the parties seeking justice.

In our study, several things were found: firstly, the formulation of Law number 45 of 2009 in consideration did not include Law number 17 of 1985 concerning the legalization of Unclo's82 as the mother of international sea law which should be a reference for every regulation concerning marine affairs. Likewise, it does not include Law number 5 of 1983 concerning ZEEI which is a reference in discussing ZEEI. Since 1983, the investigative apparatus at ZEEI is only the Navy but with Law number 31 of 2004 concerning fisheries, police officers have entered as investigators at ZEEI, but since the enactment of Law number 45 of 2009, the number of freies Ermessen has been given to the Navy and PPNS fisheries which be an investigator at ZEEI. ZEEI as a special territorial territory due to the existence of other countries' rights as in article 58 (1) (2) Law number 17 of 1985 concerning the ratification of Unclo's 1982, then in understanding law enforcement is not only the interests of welfare but also the interests of maintaining sea security. Therefore, the Government in giving Freies Ermessen to certain institutions as investigative officers must consider capabilities in the legal and security professions and must be guided by the International Law of the Sea. The rights of other countries to exercise the right of freedom of navigation on ZEEI by government vessels, warships, and other fishing vessels also have the potential to disrupt security at ZEEI. Some cases that occur in EEZ such as escort of foreign fishing vessels in LCS by government vessels of other countries show that EEZ is a marine regime that still leaves a difference in the interpretation of the articles about ZEE in Unclo's 82. This should be a consideration for who the Freies Ermessen was given, of course, only to institutions that met the professional requirements as law enforcement and security enforcement at sea and had the facilities and professional human resources to carry out both tasks. The two KKN PPNS investigators are civil investigators according to the KUHAP article, the sea area which is the area of law enforcement operations is the Indonesian sovereignty territory of Indonesia or up to the territorial sea only. If this officer is forced to be given Freies Ermessen as an investigator up to ZEEI it will violate the Criminal Procedure Code and if given the task for security aspects it will violate the nature of the civil law enforcement apparatus.

Third, Understanding Article 9 of the Criminal Procedure Code mandates the existence of their respective legal areas in accordance with the provisions of the law, meaning that each investigator with his Freies Ermessen given needs to be included in the area where his Freies Ermessen operate. With 2 investigators operating at ZEEI, it has the potential to cause legal problems, namely when investigating or investigating at sea. The operation of the two investigators is not regulated in the Law so that the potential for duplication and detrimental examination because some rights are not fulfilled. Fourth, the relationship between police investigators and PPNS 
investigators is that the Police are considered to have a higher level of professionalism. This is quite reasonable because the National Police in the history of its assignment since the inception of the National Police professional investigator is a complete possession, while fisheries PPNS assignments as investigators are given along with the birth of the 2004 Fisheries Law. According to article 73 (2) of Law number 45 concerning changes to the Law number 31 of 2004 concerning fisheries, PPNS fisheries were given Freies Ermessen as an investigator at ZEEI while the National Police did not, a contradiction occurred with the position of the police who certainly had more experience in law enforcement.

\section{Conclusions}

Making laws that are not comprehensive in listing considerations and legal basis and the absence of synchronization of norms within them will cause overlap. Overlapping of the authority of the investigative authorities in ZEEI resulted injustice in the legal process not being achieved. For the Indonesian state, this will be detrimental because marine resources especially fish is a natural wealth that can be used as a source of prosperity for the people.

Indonesia's exclusive economic zone is a special zone that must be specifically regulated because in the management of this zone it also accommodates the interests of other countries in accordance with Unclo's mandate. In the context of law enforcement, it must be appropriate and correct in granting authority to government agencies which professionally and the capabilities of other facilities and infrastructure meet the requirements as law enforcement officers.

\section{Reference}

Ateng Syafrudin, Menuju Penyelenggaraan Pemerintahan Negara Yang Bersih dan Bertanggung jawab, Jurnal Pro Justisia Edisi IV, 4(1):12-26, 2000.

Gatot Supramono, Hukum Acara Pidana Dan hukum Pidana Di bidang Perikanan, (Jakarta: Rineka Cipta, 2011). Mochtar kusumaatmaja, hukum laut internasional, Bandung: Binacipta, 1978).

Peter Mahmud Marzuki, Penelitian Hukum, (Jakarta : Kencana Prenada Media, 2001).

Purnadi Pubacaraka and Soerjono Soekanto, Perihal Kaedah Hukum, (Bandung : Alumni, 1978).

Philipus M. Hadjon, Tentang Wewenang, paper, (Surabaya : Universitas Airlangga, without year).

Nomensen Sinamo, Ilmu perundang-undangan,(Jakarta: Jala permata aksara, 2016).

Ridwan Eko Prasetyo, Hukum Acara Pidana, (Bandung: Pustaka Setia, 2015).

\section{Laws And Regulations}

Republic of Indonesia, Constitution of the Republic of Indonesia, 1945.

Republic of Indonesia Law number 8 of 1981 concerning KUHAP.

Republic of Indonesia Law Number 45 of 2009 concerning Amendments to Law Number 31 of 2004 concerning Fisheries.

Republic of Indonesia Law Number 5 of 1983 concerning Exclusive Economic Zones and the United Nations Convention on The Law of the Sea 1982. 